\title{
Aims and Scope
}

The Canadian Journal of Philosophy was founded in 1971 ty four Albertan philosophers: John King-Farlow, Kai Nielsen, T.M. Penelhum, and W.W. Rozeboom. Since its founding, the CJP has grown into a widely respected philosophy journal with an international reputation. The CJP aims to publish the best work in any area of philosophy in French or English. It receives close to 300 submissions every year from an international commurity of authors, and it uses a distinguished international list of philosophers to referee these submissions. All papers are selected on the basis of whether they make significant, original contributions to the philosophical debates they address. CJP's annual acceptance rate is typically close to $8 \%$.

In addition to its regular issues, CJP regularly publishes special issues on topics of current philosophical interest.

CJP is registered in Alberta as a private not-for-profit corporation. It is managed by its Board of Editors.

\section{Peer Review Statement}

All articles are subject to initial blind-review by the Editorial Board Coordinator and in most cases a second blindreview by an Editorial Board Member. If found suitable for further conisideration, articles are then subject to peer review by two independent, anonymous expert referees. At this point the Editorial Board Member sees the identity of the author to help them select unbiased referees. Finally, after receiving the referee reports, the Editorial Board Member may recommend that the submission be accepted for publication. All members of the Editorial Board blind-vote on the recommendation.

\section{Preparing and submitting your manuscript}

Before preparing your submission, please visit the Canadian Journal of Philosophy homepage at http://www. tandfonline.com/rcjp for full instructions for authors.

Papers for consideration should be submitted to the Editorial Assistant, Jason Poettcker, at: cjp@philosophy.ryerson. ca. Authors are encouraged to submit manuscripts electronically. Electronic submissions should be sent as email attachments using a standard program such as MS Word.

The CJP will normally not consider manuscripts exceeding 10,000 words, including notes. Manuscripts should be prepared for blind review, which means they should contain no self-identifying references in either text or footnotes. An abstract of 150 to 250 words should also be included.

\section{Editorial Office \\ Canadian Journal of Philosophy \\ Department of Philosophy \\ Ryerson University \\ 350 Victoria Street \\ Toronto, ON M5B 2K3 \\ Canada \\ cjp@philosophy.ryerson.ca}

Please make sure that your contact details are clearly visible on the outside of all packages you send to the Editorial Office.

Submitted manuscripts are subject to peer review at the discretion of the Editorial Office. In order to maintain anonymity during any refereeing process, authors are requested to refrain from, or keep to a minimum, self-referencing.

There are no page charges in Canadian Journal of Philosophy.

\section{Copyright}

It is a condition of publication that all contributing authors grant to Canadian Journal of Philosophy the necessary rights to the copyright in all articles submitted to the Journal. Authors are required to sign an Article Publishing Agreement to facilitate this. This will ensure the widest dissemination and protection against copyright infringement of articles. The "article" is defined as comprising the final, definitive, and citable Version of Scholarly Record, and includes: (a) the accepted manuscript in its final and revised form, including the text, abstract, and all accompanying tables, illustrations, data; and ( $b$ ) any supplementary material. Copyright policy is explained in detail at http://journalauthors. tandf.co.uk/preparation/copyright.asp.

Authors are themselves responsible for obtaining permission to reproduce copyright material from other sources.

\section{Free article access}

Ascorresponding author, you will receive free access to yourarticleonTaylor \&Francis Online.Youwillbegiven access to the Mvauthored workssection of Taylor \& Francis Online, which shows youallyour published articles. You can easily view, read, and download your published articles from there. In addition, if someone has cited your article, you will be able to see this information. We are committed to promoting and increasing the visibility of your article and have provided this guidance < http://journalauthors.tandf.co.uk/beyondpublication/promotearticle.asp > on how you can help.

\section{Reprints and journal copies}

Corresponding authors can receive a complimentary copy of the issue coniaining their article. Article reprints can be ordered through Rightslink ${ }^{\otimes}$ when you receive your proofs. If you have any queries about reprints, please contact the Taylor \& Francis Author Services team at reprints@tandf.co.uk. To order extra copies of the issue containing your article, please contact our Customer Services team at adhoc@tandf.co.uk.

For further information about Taylor \& Francis journals please visit www.tandfonline.com.

If you are unable to access our websites, please write to: Canadian Journal of Philosophy, Editorial Department, Taylor 


\section{CONTENTS}

\section{Articles}

Human rights and the rights of states: a relational account

Ariel Zylberman

Psychopathy and internalism

Victor Kumar

A new moral sentimentalism

Eric Vogelstein

The reversal test, status quo bias, and opposition to human cognitive enhancement Steve Clarke

The problem of empty names and Russellian Plenitude

Joshua Spencer

Is ontological revisionism uncharitable?

Chris Daly and David Liggins

Mental powers and the soul in Kant's Subjective Deduction and the Second Paralogism

Steven Tester 